\title{
The Identification of Electrolyte Property of Humus-Contained Andosol Soil Using Cu-Zn Electrodes
}

\author{
Irvan Maulana Firdaus ${ }^{* 1,2}$, Diva N.M.D. Masyithoh ${ }^{2}$, Tharra A.N. Azizah'2, Febiyanto1,3 \\ ${ }_{1}^{1}$ Department of Chemistry Universitas Jenderal Soedirman Purwokerto \\ ${ }^{2}$ Sekolah Menengah Atas Al Irsyad Al Islamiyyah Boarding School Purwokerto \\ ${ }^{3}$ Department of Chemistry Universitas Gadjah Mada Yogyakarta \\ *E-mail: irvanmaulanafirdaus@gmail.com
}

\begin{abstract}
Abstrak
Penelitian ini bertujuan untuk menginvestigasi sifat elektrolit dalam tanah andosol yang mengandung senyawa humus menggunakan sel Volta. Elektroda yang digunakan adalah Cu dan Zn sebagai masing-masing elektroda katoda dan anoda. Penelitian ini dilakukan dengan memvariasikan luas area elektroda yakni 20,30, dan $40 \mathrm{~cm}^{2}$, sedangkan variasi jarak elektroda adalah 3, 4, dan $5 \mathrm{~cm}$. Profil arus dan tegangan yang dihasilkan pada sistem sel Volta diukur dengan menggunakan multimeter digital. Hasil penelitian menunjukkan bahwa tanah andosol memiliki sifat elektrolit. Sifat elektrolit ini dapat dihasilkan karena adanya senyawa humus yang tinggi akan kapasitas tukar kationnya. Selain itu, peningkatan luas area elektroda maka akan meningkatkan arus dan tegangannya. Sebaliknya, arus dan tegangan yang meningkat dihasilkan dengan semakin pendeknya jarak diantara dua elektroda. Selanjutnya, penggunaan sistem sebanyak 24 sel Volta menunjukkan peningkatan yang sangat signifikan dibandingkan dengan sel tunggal. Hal ini menunjukkan bahwa peningkatan arus dan tegangan secara relatif proposional dengan banyaknya sel Volta yang digunakan. Penelitian ini dapat menjadi acuan sederhana dalam mengidentifikasi sifat elektrolit dalam bahan alam atau limbah.
\end{abstract}

Kata kunci: tanah andosol; sifat elektrolit; humus; sel volta; elektroda $\mathrm{Cu}-\mathrm{Zn}$

\begin{abstract}
This study investigated the electrolyte property of humus-contained andosol soil using Volta cell. The electrodes that are used were $\mathrm{Cu}$ and $\mathrm{Zn}$ for cathode and anode, respectively. This research was done by varying electrode area and distance between $\mathrm{Cu}$ and $\mathrm{Zn}$ electrodes. The varied electrode area was 20,30, and $40 \mathrm{~cm}^{2}$, whereas the electrode distance was 3, 4, and $5 \mathrm{~cm}$. Then, the current and voltage profiles of Volta cell system were measured using a digital multimeter. The result showed that humus-contained andosol soil has an electrolyte property. Electrolyte property of andosol soil might be due to the humus substance that has a high cationic-exchange capacity. Besides, it showed that the increase of the electrode area, the current and voltage were increased gradually. In contrast, the increase in current and voltage could be found by the decrease of electrode distance. In addition, the use of 24-Volta cells system enhancing current and voltage compared to a single cell. It suggests that the increase of current and voltage was relatively
\end{abstract}


proportional to the number of Volta cell. Therefore, this research can be a reference for the identification of electrolyte property of natural or waste materials.

Keywords: Andosol soil; electrolyte property; humus; Volta cell; Cu-Zn electrodes

\section{Introduction}

In an aqueous phase, the electrolyte property means that electron-transporting medium, while the non-electrolyte is vice versa. In this system, when two electrodes are entered into the electrolyte medium, and then the electricity can be produced spontaneously under a chemical reaction (Kholida \& Pujayanto, 2015). The compound dissolution can cause the electrolyte property into ions, and thus the system becomes an electronic conductor. It is found in water, acid, base or the other chemical compounds (Prayudha et al., 2019). However, it may also be found in the sol and solid-state phase, as reported by Azizah et al. (2015) and Mustaqim et al. (2017).

Previous research showed that electrolyte property could be observed in the saltwater (Usman et al., 2017; Haq et al., 2018). A similar report, Pauzi et al., (2018) was also investigated the electrolyte property in the seawater. Moreover, the seawater was researched for dry battery by Mardwianta (2017). Prayogi (2018) reported the use of wuluh starfruit and mengkudu electrolyte for 12 Volt car's battery. Suciyati et al. (2019) investigated the electrolyte solution of orange fruit. In our recent work showed that the electrolyte property could be resulted by using the waste of pineapple peel (Ananas comosus L.) (Firdaus et al., 2019).

The electrolyte property of medium is not only found in the aqueous or liquid phase but also solid-phase like a soil-based medium. Generally, the soil has electrolyte properties caused by water content in the ground (Yanto, 2008). Montmorillonite claycontained soil type has high water absorption ability due to the lattice structures, which quickly expands (Lestari, 2014). It may show an electrolyte-like property caused by water content. However, there are a lot of soil types that could be observed for the identification of electrolyte property. One of them is andosol soil.

The andosol soil has a black color which is composed of a humus organic compound with a high cation exchange capacity (Sufardi and Muyassir, 2017; Candra et al., 2016). The high cation exchange capacity of humus-contained andosol soil provides calcium, manganese, potassium, and sodium ions. When it is dissolved in water, then it possibly becomes an electrolyte medium. Nevertheless, as far as we know, there is no discussion or explanation elsewhere in understanding the electrolyte characteristic of andosol soil. Therefore, it is essential to conduct the electrolyte property of the andosol soil.

To identify the electrolyte property of andosol soil, this will be carried out using $\mathrm{Cu}$ and $\mathrm{Zn}$ electrodes of homemade Volta cell. Here, the use of $\mathrm{Cu}$ and $\mathrm{Zn}$ electrodes has been reported before (Yulianti, 2016; Usman et al., 2017; Pauzi et al., 2018) and showed a good and viable-electrode. In addition, for the Volta cell compartment, the variation in electrode area and distance should be considered. Based on previous reports, Fadli et al. (2012) reported that the variation in electrode area and distance relatively gave an impact to the electrolyte property of pineapple fruit. The electrode distance was also written by Imamah (2013). This research showed that a longer electrode distance would significantly reduce the current and voltage of bio-battery of Citrus sp. waste. Moreover, this similar research was also supported by Asmarani (2017). Therefore, the identification of electrolyte property of humus-contained andosol soil and the effect of varied electrode area and distance on the current and voltage characteristics will be observed and presented in this paper. 


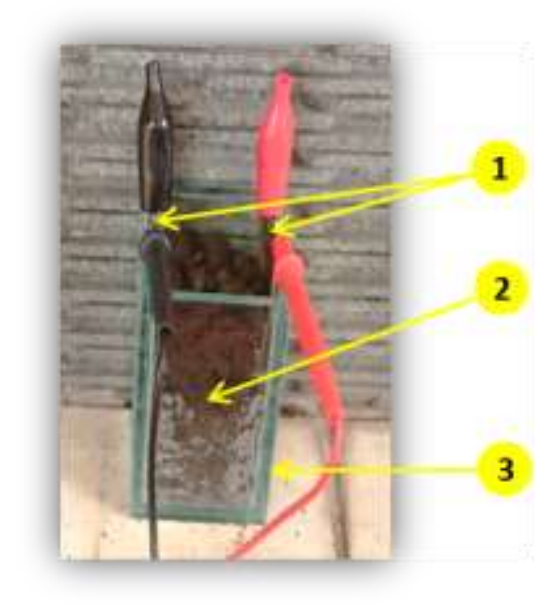

Figure 1. A homemade-Volta cell consisted (1) electrodes which were red and black color for $\mathrm{Cu}$ and Zn, respectively, (2) andosol soil, and (3) transparent-glass.

\section{Method}

Materials

Materials that are used were andosol soil and commercially distilled water. The chamber consisted of $\mathrm{Cu}$ and $\mathrm{Zn}$ electrodes for cathode and anode, clamp, and digital multimeter Osmond DT-9205A. In addition, andosol soil was taken from Banyumas Regency and around the hill of Slamet mountain.

\section{Single-Volta cell reactor setting}

The single Volta cell was formed using a homemade transparent-glass chamber. The chamber has a dimension of 5 x $5 \times 10 \mathrm{~cm}$ in size. The illustration of single Volta cell reactor depicted in Fig. 1.

\section{Determination of electrode area effects}

The electrode area effects were determined following Usman et al. (2017) with modification. An amount of 120 gr of andosol soil was weighed and entered into a glass reactor. Then, andosol soil was added with $10 \mathrm{~mL}$ of distilled water. The electrodes of $\mathrm{Cu}$ and $\mathrm{Zn}\left(\mathrm{A}=20 \mathrm{~cm}^{2}\right)$ was also entered into the glass reactor with the distance (d) was $5 \mathrm{~cm}$. The experiment was repeated using the electrode area of $A=30$ and $40 \mathrm{~cm}^{2}$, respectively. Then, the voltage and current were measured by a digital multimeter. The maximum condition was used for further investigation.

\section{Determination of electrode distance effects}

The electrode distance effects were determined following Usman et al. (2017) with modification. An amount of 120 gr of andosol soil was weighed and entered into a glass reactor. Then, andosol soil was added with $10 \mathrm{~mL}$ of distilled water. The electrodes of $\mathrm{Cu}$ and $\mathrm{Zn}$ under the maximum electrode area condition was also entered into the glass reactor with the distance (d) of them was $5 \mathrm{~cm}$. The experiment was repeated using $\mathrm{d}=4$ and $3 \mathrm{~cm}$, respectively. Then, the voltage and current were measured using a digital multimeter. The maximum result of electrode distance was used for further investigation.

\section{Determination of electrolyte property using the 24-Volta cells compartment}

An appropriate of $120 \mathrm{gr}$ of andosol soil was weighed and separately entered into twenty-four glass reactors. Then, the andosol soil was added with $10 \mathrm{~mL}$ of distilled water. The electrode area and distance of $\mathrm{Cu}$ and $\mathrm{Zn}$ with the maximum condition were also entered into the glass reactor. The twentyfour Volta cells were arranged through a series-parallel system as an illustrated picture in Fig. 2. Subsequently, the voltage and current were measured using a digital multimeter. 


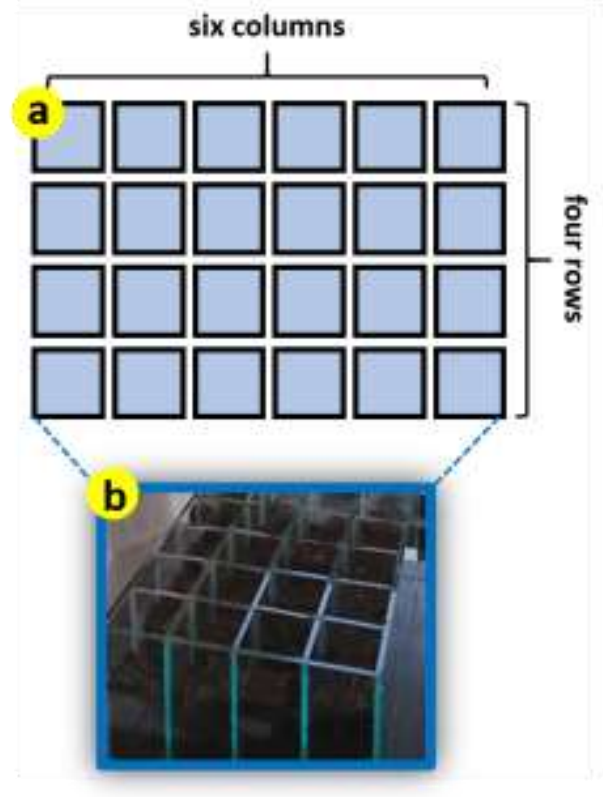

Figure 2. Twenty-four-packed glass reactor arrangement. They will be mentioned as a 24Volta cells compartment. Illustration scheme (a) and experiment condition (b), respectively.

\section{Results and Discussion}

\section{Determination of electrode area effects}

As-resulted voltage and current by varying the electrode area were shown in Fig. 3 (a) and (b). Based on Fig. 3 (a), the varied electrode area gave the different value of voltage. A high electrode area slightly increased its voltage and vice versa.

Table 1. Summary of voltage and current characteristics under various electrode area.

\begin{tabular}{cccc}
\hline \multirow{2}{*}{ Parameters } & \multicolumn{3}{c}{ Electrode area $\left(\mathbf{c m}^{2}\right)$} \\
\cline { 2 - 4 } & $\mathbf{2 0}$ & $\mathbf{3 0}$ & $\mathbf{4 0}$ \\
\hline Voltage $(\mathrm{V})$ & 0.889 & 0.899 & 0.904 \\
Current $(\mathrm{mA})$ & 0.02 & 0.05 & 0.06 \\
\hline
\end{tabular}

In addition, the current characteristics also showed a similar trend. The current enhanced gradually with the improved electrode area, as shown in Fig. 3 (b). Table 1 shows the summary data of asresulted voltage and current through various electrode area. It concluded that the maximum condition was merely observed in the electrode area of $40 \mathrm{~cm}^{2}$.
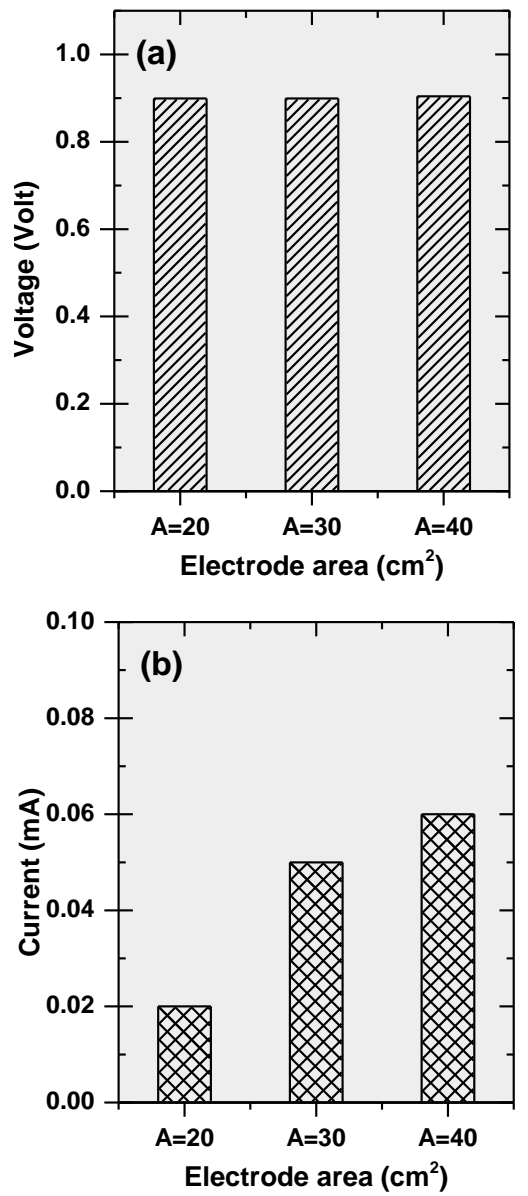

Figure 3. Voltage (a) and current (b) characteristics under various electrode area.

\section{Determination of electrode distance effects}

The voltage and current of andosol soil medium under various electrode distances were shown in Fig. 4 ((a)-(b)) and Table 2. This treatment was done using the maximum condition of the electrode area $\left(\mathrm{A}=40 \mathrm{~cm}^{2}\right)$.

Fig. 4 (b), by varying the electrode distances strictly influencing the current profiles compared to the electrode area treatment, as shown in Fig. 3 (b). However, their voltage relatively led the same (Fig. 4 (a)).

Based on the results above, neither electrode area nor electrode distance variations, they do not significantly enhance their voltage profiles than its currents. However, the decrease of electrode distance 
has remarkably improved the current than the electrode area effect. The electrical resistance might cause the low current in the Volta cells compartment. A higher electrical resistance can be generated with the larger electrode distance between them. Considering the Ohm's law: $I=V / R$ where $I, V$, and $R$ are current, voltage, and electrical resistance, respectively; it explains that the increase of current following with the decrease of the electrical resistance and vice versa.
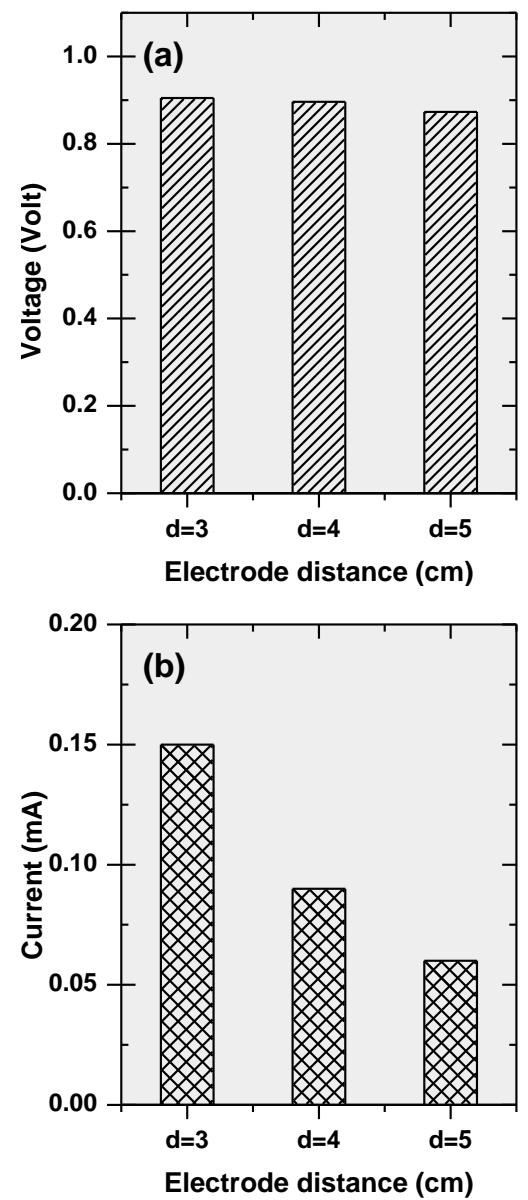

Figure 4. Voltage (a) and current (b) characteristics under various electrode distance.

Table 2. Summary of voltage and current characteristics under various electrode distance.

\begin{tabular}{cccc}
\hline \multirow{2}{*}{ Parameters } & \multicolumn{3}{c}{ Electrode distance (cm) } \\
\cline { 2 - 4 } & $\mathbf{3}$ & $\mathbf{4}$ & $\mathbf{5}$ \\
\hline Voltage (V) & 0.905 & 0.896 & 0.873
\end{tabular}

\begin{tabular}{llll} 
Current $(\mathrm{mA})$ & 0.15 & 0.09 & 0.06 \\
\hline
\end{tabular}

In addition, the above equation correlated with the following formula: $R=\rho l / A$ where $R, \rho, l$, and $A$ are electrical resistance, resistivity, electrode distance, and cross-sectional area, respectively (Amal et al., 2016; Darmawan et al., 2006). The formula performed that a high electrode area can decrease the electrical resistance. Hence, the low-resistance value can promote the current, which coincided with the Ohm's equation. Therefore, the high electrode area was able to enhance its current well, as shown in Fig. 3 (b).

\section{Determination of electrolyte property using the 24-Volta cells compartment}

The andosol soil has a high organic compound and water content. It might be formed by the presence of the natural vegetation and organic accumulation of humus underneath the ground (Candra et al., 2016; Mukhlis, 2011). The electrolyte property measurements of humus-contained andosol soil using 24-Volta cells reactor were performed in Table 3 .

Based on Table 3, generally, it shows that the increase of number Volta cell could dramatically increase the current and voltage as well. The current and voltage were increased three times higher compared to the resulted data, as shown in Tabel 1 and 2 (Fig. 3 and 4). Moreover, corresponding with the other reports, our result is relatively still higher. For examples, Imamah (2013), biobattery using Citrus sp. with series-parallel compartment resulted in the voltage approximately $1.58,1.54$, and $0.67 \mathrm{~V}$ for $\mathrm{Cu}$ $\mathrm{Fe}, \mathrm{Cu}-\mathrm{Pb}, \mathrm{Cu}-\mathrm{Al}$ electrode pairs, respectively. Suryaningsih (2016), by using $\mathrm{Cu}$ and $\mathrm{Zn}$ electrodes, the current and voltage of 100 $\mathrm{mL}$ of wuluh starfruit were $0.72 \mathrm{~V}$ and 0.29 $\mathrm{mA}$, respectively.

Electrical power meaning that a needed or produced energy on the circuit or compartment (Arizal et al., 2017). Given the system (Fig. 2), it had the electrical power of $0.0552 \mathrm{~mW}$. However, the result was 
proportional with their resulted current and voltage by applying the formula as follows $P=V . I$, were $P, V$, and $I$ are electrical power, voltage, and current, respectively (Giancoli, 2001; Mardwianta, 2017; Nirmalasari et al., 2015). It concluded that the use of 24 -Volta cells leads to an increase in current and voltage as same as its electrical power. This phenomenon was similar to previous research which is reported by Suryaningsih (2016), Nurhayati and Maina (2019), and Firdaus et al. (2019). They stated that the more Volta cell or medium would increase their current and voltage, gradually.

Table 3. Voltage and current measurements using the 24-Volta cells compartment.

\begin{tabular}{ccc}
\hline Iaverage $(\mathbf{m A})^{*}$ & Vaverage $(\mathbf{V})^{*}$ & $\begin{array}{c}\text { Electrical power } \\
\text { average }(\mathbf{m W})^{*}\end{array}$ \\
\hline 0.315 & 1.75 & 0.552 \\
\hline *data was repeated three times. &
\end{tabular}

\section{Conclusion}

In this work, this study summarized that humus-contained andosol soil has electrolyte property well. However, by varying the electrode area and distance gave an effect to the current and voltage characteristics of samples. Although, the electrode distance has remarkably increased the current than varied electrode area. Meanwhile, the voltage showed relatively the same. In addition, the 24-Volta cells showed a significant increase in their current and voltage profiles than a single cell. Finally, this simple research can be a reference for further exploration of the other natural sources or waste-based electrolyte medium.

\section{Acknowledgements}

The authors thank headmaster, teachers, and friends of Sekolah Menengah Akhir (SMA) Al Irsyad Al Islamiyyah Purwokerto Banyumas Jawa Tengah Indonesia for meaningful supports and discussions. Indeed, this simple research may inspire and useful to explore the electrolyte property of natural resource for the students of junior and senior high school in Indonesia.

\section{References}

Amal, M.S.K, Febiyanto, Soleh, A., \& Afif, M. 2016. Elektrodekolorisasi limbah cair pewarna batik dengan memanfaatkan batang karbon dari limbah baterai bekas. Jurnal MIPA. $39(2), 135-142$.

Arizal, F., Hasbi, M., \& Kadir, A. 2017. Pengaruh kadar garam terhadap daya yang dihasilkan pembangkit listrik tenaga air garam sebagai energi alternatif terbaharukan. Enthalphy-Jurnal Ilmiah Mahasiswa Teknik Mesin. 2(1), 1-5.

Asmarani, S. 2017. Analisis jeruk dan kulit jeruk sebagai larutan elektrolit terhadap kelistrikan sel Volta [Skripsi]. Jurusan Fisika. Fakultas MIPA. Universitas Lampung. Lampung.

Azizah, S. N., Nuryanto, R., \& Taslimah. 2015. Pengaruh variasi $\mathrm{pH}$ sol terhadap karakteristik produk pada pembuatan elektrolit padat $\mathrm{NaMn}_{2}$ ${ }_{x} \mathrm{Co}_{\mathrm{x}} \mathrm{O}_{4}$ dengan metode sol-gel. Jurnal Kimia Sains dan Aplikasi. 18(2), 3943.

Candra S., Kemala S.L., \& Purba, M. 2016. Evaluasi kadar air tanah, bahan organik, dan liat serta kaitannya terhadap indeks plastisitas tanah pada beberapa vegetasi di Kecamatan Pamatang Sidamanik Kabupaten Simalungun. Jurnal Agroteknologi. 4(4), 2420-2427.

Darmawan, A., Suhartana \& Kristinawati, L. 2006. Koagulasi pewarna indigo karmina (Disodium-3,3'-dioxo-2,2'-biindolylidene-5,5'disulfonat) dengan metode elektrolisis menggunakan anoda seng. Jurnal Kimia Sains dan Aplikasi. 9(1), 22-27.

Fadli, U.M., Legowo, B., \& Purnama, B. 2012. Demonstrasi sel Volta buah nanasa (Ananas Comosus L. Merr). Indonesian 
Journal of Applied Physics. 2(2), 176183.

Firdaus, I.M., Silvia, R.D., Amin, A.F., Tsaqifa, R.V., Purama, I., \& Febiyanto. 2019. The study of pineapple peel (Ananas comosus L.) waste-based electrolyte medium: A simple experiment design for the students. Walisongo Journal of Chemistry. 2(2), 89-96.

Giancoli, D.C. 2001. Fisika Edisi 1 Jilid 2. Erlangga. Jakarta.

Kholida, H. \& Pujayanto. 2015. Hubuangan kuat arus listrik dengan keasaman buah jeruk dan mangga. Prosiding Seminar Nasional Fisika dan Pendidikan Fisika (SNFPF) ke-6 2015. 6(1), 42-46.

Lestari, I.G.A.I. 2014. Karakteristik tanah lempung ekspansif (studi kasus di Desa Tanah Awu, Lombok Tengah). GaneC Swara. 8(2), 15-19.

Haq, S. Z. N., Kurniawan, E., \& Ramadhan, M. 2018. Analisis pembangkit elektrik menggunakan media garam sebagai larutan elektrolit. E-proceeding of Engineering. 5(3), 3823-3830.

Imamah, A.N. 2013. Efek variasi bahan elektroda serta variasi jarak antar elektroda terhadap kelistrikan yang dihasilkan oleh limbah buah jeruk (Citrus sp.) [Skripsi]. Jurusan Fisika. FMIPA. Universitas Jember. Jember.

Mardwianta, B. 2017. Pembangkit energi listrik pada baterai udara dengan bahan karbon aktif dan elektrolit air laut, Seminar Nasional Teknologi Informasi dan Kedirgantaraan (SENATIK). 21, 1-8.

Mukhlis. 2011. Tanah andisol-genesis, klasifikasi, karakteristik, penyebaran, dan analisis. USU-Press, Medan.

Mulyadi, R., Artika, K.D., \& Khalil, M., P. 2019. Perancangan sistem kelistrikan perangkat elektronik pada mobil listrik. Jurnal Elemen. 6(1), 7-12.
Mustaqim, Haris, A., \& Gunawan. 2017. Fabrikasi dye-sensitized solar cell menggunakan fotosensitizer ekstrak bunga rosela (Hibiscus sabdariffa L.). Jurnal Kimia Sains dan Aplikasi. 20(1), 62-67.

Nirmalsari, I., Putram A.E., \& Prastowo, B.N. 2015. Purwarupa alat ukur daya litsrik berbasis netduino plus. IJEIS. 5(1), 21-30.

Nurhayati \& Maina. 2019. Pengkuran nilai tegangan listrik pada buah nanas. Jurnal Phi. 2019(2), 1-3.

Pauzi, G. A., Randha, K. A., Amir, S., Sri, W. S., Arif, S., Junaidi, \& Warsito. 2018. Desain dan realisasi akumulator elektrolit air laut dengan penambahan sodium bikarbonat $\left(\mathrm{NaHCO}_{3}\right)$ sebagai sumber energi alternatif. Jurnal Fisika. 8(2), 78-85.

Prayudha, J., Pane, U. F. S. S., Saniman, \& Raharjo, S. 2019. Implementasi metode Fuzzy untuk identifikasi kadar elektrolit untuk mengukur tingkat kesuburan tanah berbasis mikrokontroler Arduino. J-SISKO TECH: Jurnal Teknologi Sistem Informasi dan Sistem Komputer TGD. 2(1), 92-106.

Suciyati, S. W., Asmarani, S., \& Supriyanto, A. 2019. Analisis jeruk dan kulit jeruk sebagai larutan elektrolit terhadap kelistrikan sel Volta. Jurnal Teori dan Aplikasi Fisika. 7(1), 7-15.

Sufardi, L. M. \& Muyassir. 2017. Pertukaran Kation pada beberapa Jenis Tanah di Lahan Kering Kabupaten Aceh Besar Provinsi Aceh Indonesia, Prosiding Seminar Nasional Pascasarjana Unsyiah, Aceh.

Suryaningsih, S. 2016. Belimbing wuluh (Averrhoa Blimbi) sebagai sumber energi dalam sel Galvani. Jurnal Penelitian Fisika dan Aplikasinya (JPFA). 6(1), 11-17. 
Usman M. A., Muhammad H., \& Budiman S. 2017. Studi eksperimen penggunaan air garam sebagai sumber energi alternatif. Enthalphy-Jurnal Ilmiah Mahasiswa Teknik Mesin. 2(2), 1-6.

Yanto, B.R. 2008. Pendekatan nilai kepadatan dan daya dukung tanah kohesif di lapangan menggunakan alat uji resistivity meter (tahanan jenis)/geolistrik [Skripsi]. Jurusan Teknik Sipil. Fakultas Teknik dan Ilmu Komputer. Universitas Komputer Indonesia. Bandung.

Yulianti, D. 2016. Analisis kelistrikan sel Volta memanfaatkan logam bekas [Skripsi]. Jurusan Fisika. Fakultas MIPA. Universitas Lampung. Lampung. 